\title{
Maxim of Cooperative Principle Violation by Dodit Mulyanto in Stand-up Comedy Indonesia Season 4
}

\author{
Ahmad Ulliyadhi Satria Raharja \\ Pasca Sarjana Universitas Negeri Semarang, Jawa Tengah, Indonesia \\ ahmadulliyadhi@gmail.com \\ Alfin Rosyidha \\ Department of English, Mangalore University, Karnataka, India \\ alfinrosyidha@gmail.com \\ DOI: http://dx.doi.org/10.1836/jopr.v1i1.62-77
}

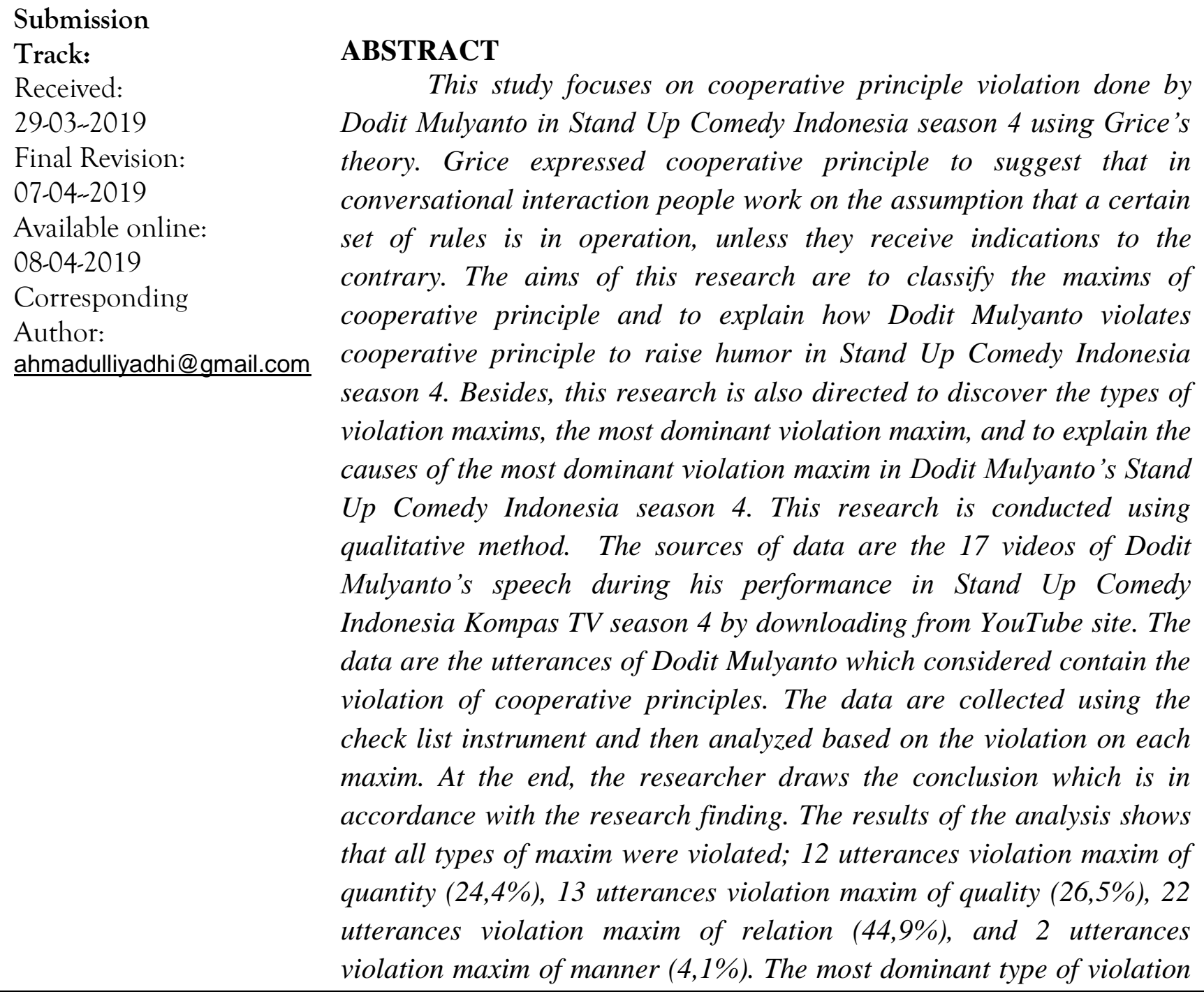


maxims was the violation maxim of relation because Dodit Mulyanto delivered too much message, which is unmatched with the topic or changed conversation topic abruptly or did the wrong causality, than is required to raise humor in Stand Up Comedy Indonesia Kompas TV season 4.

Keywords: Cooperative Principle, Maxim Violation, Stand Up Comedy.

\section{INTRODUCTION}

The language used in daily life is a unique, arbitrary, and conventional sign system / emblem / speech sound which is used by the public in order to communicate each other. According to Longman Advanced American Dictionary (2007, p. 895), language is a system of communication by written or spoken words which is used by the people of a particular country or area. The language built from the habits and the geographical area where the speakers are living. Good language developed based on a certain system and a set of rules were observed by the speakers.

Originally, the function of language is as a communication tool (Bühler (1934) in Diessel, 2014, p.3). Hence, the language has more specialized function that is for establishing relationships, solidarity, and cooperation within the community, the language had been used to express mind with the feeling so that the listener will able to sense what is discussed about. As a communication tool, the language is used to convey the ideas, feeling, whether real or imagination. The imagination function is usually in the form of art works, including poetry, stories, fairy tales, and jokes. In the jokes, language is used as a communication tool by violating maxims of communication, they are cooperative principle and politeness principle maxim.

The linguistics which examines the violations of maxims in communication is pragmatic. Pragmatics is the study of language from the point of view of users, especially of the choices they make, the constrain they encounter in using language in social interaction and the effect their use of language has on other participant in the act of communication (Crystal 
1985 in Kasper 1997). It is clear that pragmatics is the study about relation between language and context that are used in community.

The violation of cooperative maxims commonly used in creating humor. The utterances that made by Stand Up comedian (comic) in Stand Up Comedy Indonesia (SUCI) event on Kompas TV -in this case Dodit Mulyanto- shaping a discourse based on a predetermined theme. The discourse is about the problems in society and attractively packaged in humor and tends to give the information in the form of persuasive discourse to the viewers of Stand up Comedy to provide a solution to these problems.

Indeed, after the writer, watched the Stand Up Comedy season 4 show, he found some phenomena that make him interested in knowing more about the language of humor used by Dodit Mulyanto in Stand Up Comedy Indonesia season 4 through pragmatic study and to find out how Dodit uses the language to raise the humor on his show at Stand Up Comedy Indonesia Kompas TV.

The research questions of the present study are what the maxims of cooperative principle which are violated by Dodit Mulyanto in Stand Up Comedy Indonesia season 4 in order to raise humor and how does Dodit violate cooperative principle to raise humor in Stand Up Comedy Indonesia season 4.

\section{LITERATURE REVIEW}

This chapter discusses some related literature that consists of the definition of pragmatics, the theory of cooperative principle, the theory of politeness principle, and the definition of maxim violation.

\section{Pragmatics}

There are some definitions about pragmatics that can help us to understand it deeply. Grundy (2000, p.3) states: "Pragmatics is about explaining how we produce and understand such every day, but apparently rather peculiar uses of language." It means that pragmatics, the study explains us how to produce utterances and comprehend what people say in daily conversation although maybe they use unfamiliar language. 
Leech (1983, p.11) explains that general pragmatics is abstraction between the study of language in total abstraction from the situation, and the study of more socially specialized uses of language. Hence, it is clear that pragmatics is the study about the relation between language and context that are used in the community.

Levinson (1983, p.9) gives a definition that pragmatics is the study of those relations between language and context that are grammaticalzed, or encoded in the structure of a language. This means pragmatics has relation with grammar because what we will say must grammatically correct. Thus, this study cause us learn how to make utterances that are right in grammar and the hearer can interpret the meaning. Besides, pragmatics is a systematic way of explaining the language use in context. It seeks to explain aspects of meaning which cannot be found in the plain sense of words or structures, as explained by semantics.(Moore, 2003).

From the definitions above, it can be concluded that pragmatics is a field linguistics study which does not only explain about language but also explain how to produce and understand the language use in our real life following the factors that influence the language choice. It teaches us how to apply it in our daily life.

Pragmatics is relevant with politeness because politeness is a strategy (or series of strategies) employed by a speaker to achieve a variety of goals, such as promoting or maintaining harmonious relations (Thomas, 1995, p.157). The politeness principle including its maxims is one kind of the strategies.

\section{Cooperative Principle (CP)}

The Cooperative Principle (CP) is proposed by H. P. Grice. Grice expressed CP to suggest that in conversational interaction people work on the assumption that a certain set of rules is in operation, unless they receive indications to the contrary (Thomas, 1995, p.62). When speakers violate any of the maxims lead the addressee or hearer to make what Grice calls implicature. Those maxims will be explained as follows. 
1. Maxim of Quantity

In this maxim we must (a) Make the contribution as informative as is required for the current purpose of the exchange, (b) Do not make our contribution more informative than is required (Leech, 1983, p.8). Those rules mean that the number of utterances used to deliver message must be informative as what is required and does not more or less than it; so that, the information does not boring or disappointing.

2. Maxim of Quality

There are two rules in this maxim, they are: (a) Do not say what you believe to be false and (b) Do not say that for which you lack adequate evidence (Leech, 1983, p.8). The meaning of these rules is clear that the delivered message must be truthful and does not lack suitable evidence.

3. Maxim of Relation

In this maxim, the rule is being relevant (Leech, 1983, p. 8). The meaning of "relevant" is the connection between what the speaker says and the addressee hears is related each other.

4. Maxim of Manner

The rules are: (a) Avoid obscurity of expression, (b) Avoid ambiguity, (c) Be brief (avoid unnecessary prolixity), and (d) Be orderly (Leech, 1983, p.8). It means utterance that is conveyed must be clear. There are two kinds of clarity, clear text and clear message. Clear text is constructed by syntax and phonology of the language. Then, the clear message is when the sense of illocutionary goal conveyed is understandable.

The cooperative principle and the politeness principle have a close relationship because they study about the use of language in communication using a set of principles or maxims to manage it. Besides, the politeness principle appears to argue the cooperative principle. The politeness principle says that not all people are being cooperative in a conversation to be polite.

\section{Maxim Violation}

According to Grice (1975) in Khosravizadeh \& Sadehvandi (2011, p.1), a violation takes place when speakers intentionally refrain to apply certain maxims in their conversation to cause misunderstanding on their participants' part or to achieve some other purposes. 
Grice (1975, p.45) in Tupan \& Natalia (2008, p.68) gives the criteria of violation of maxims used as distinguished guidelines. Here are the guidelines:

1. Maxim of Quantity Violation:

a. If the speaker does circumlocution or not to the point

b. If the speaker is uninformative

c. If the speaker talks too short

d. If the speaker talks too much

e. If the speaker repeats certain words

2. Maxim of Quality Violation:

a. If the speaker lies or says something that is believed to be false

b. If the speaker does irony or makes ironic and sarcastic statement

c. If the speaker denies something

d. If the speaker distorts information.

3. Maxim of Relation Violation

a. If the speaker makes the conversation unmatched with the topic

b. If the speaker changes conversation topic abruptly

c. If the speaker avoids talking about something

d. If the speaker hides something or hides a fact

e. If the speaker does the wrong causality

4. Maxim of Manner Violation

a. If the speaker uses ambiguous language

b. If the speaker exaggerates thing

c. If the speaker uses slang in front of people who do not understand it.

d. If the speaker's voice is not loud enough.

\section{RESEARCH METHODOLOGY}

The word research comes from the verb researching which means investigate or examine. Whereas, the term methodology is derived from the word metodos and logos. 
Metodos means: way to go to achieve a goal, whereas logos means: science (Arikunto, 1990, p.16), so methodology means a science that discuss about the ways of achieving a truth. Based on the understanding above, the methodology is a way to search for truths that can be justified scientifically.

The approach for studying Dodit Mulyanto's utterances in Stand Up Comedy Indonesia is a descriptive qualitative method. Because, a qualitative approach is a research procedure that produces the descriptive data in the form of written words. The data sources in this study are the utterances of Dodit Mulyanto in Stand Up Comedy Indonesia Kompas TV season 4 by downloading from YouTube site. Furthermore, the researcher felt that the appropriate triangulation to be used in this paper is methodological triangulation. Methodological triangulation refers to the need of different instruments in gaining the data. In this case, the researcher conducted observation and transcript analysis

\section{DISCUSSION}

The data were the scripts of Dodit Mulyanto in Stand Up Comedy Indonesia Kompas TV season 4 below which analyzed by violating cooperative principles of conversation in detail. This research discovered that all types of maxims were violated and they were shown in percentage in the following table.

The percentage overview of violation maxims in Dodit Mulyanto's Stand Up Comedy Indonesia Kompas TV season 4.

\begin{tabular}{|l|l|l|l|}
\hline No. & $\begin{array}{l}\text { Types of Violation } \\
\text { Maxims }\end{array}$ & Frequency & $\boldsymbol{X}=\frac{\boldsymbol{F}}{\boldsymbol{N}} \boldsymbol{x \mathbf { 1 0 0 } \%}$ \\
\hline 1. & Quantity & 12 & $24,5 \%$ \\
\hline 2. & Quality & 13 & $26,5 \%$ \\
\hline 3. & Relation & 22 & $44,9 \%$ \\
\hline 4. & Manner & 2 & $4,1 \%$ \\
\hline
\end{tabular}




\begin{tabular}{|l|l|l|l|}
\hline & Total & 49 & $100 \%$ \\
\hline
\end{tabular}

Table above shows that there were 49 utterances violation of maxim which were used in Dodit Mulyanto's Stand Up Comedy Indonesia Kompas TV season 4. First, there were 12 utterances $(24,5 \%)$ violation maxim of quantity. Violation maxim of quantity makes the speaker always repeat the same words and does circumlocution or not to the point. Second, there were 13 utterances (26.5\%) violation maxim of quality. Dodit Mulyanto violated maxim of quality because it tend to make ironic and sarcastic statement and he said something that he believes to be false. Third, there were 22 utterances $(44,9 \%)$ violation maxim of relation. Within the four violation maxims; violation maxim of relation was the most dominant in scripts Dodit Mulyanto's Stand Up Comedy Indonesia Kompas TV season 4. Violation maxim of relation makes the speakers always to speak which is relevant. It means that there is a connection between what the speaker says and the addressee hears is related each other. Intentionally, Dodit Mulyanto in Stand Up Comedy Indonesia Kompas TV season 4 delivered too much message, which isunmatched with the topic or changed conversation topic abruptly or did the wrong causality, than is required to raise humor. Therefore, it violated the maxim of relation.

After maxim of relation, the most maxim which is used by Dodit Mulyanto is maxim of quality. Here, Dodit Mulyanto used some jokes that are believed to be false. In addition, Dodit also did irony or said sarcastic statements. Dodit Mulyanto often denied something and distorted information. All those effort are done in order to rise humor which violated maxim of quality up to 13 utterances $(26,5 \%)$ from 49 utterance which he done.

The third maxim which is often Dodit Mulyanto used to perform is maxim of quantity. He did violated maxim of quantity up to 12 utterances $(24,5 \%)$. He makes the contribution much of uninformative information as is required for the current purpose of the exchange. He also too much gave information. What he has done is violated maxim of quantity.

The last, those were 2 utterances $(4,1 \%)$ violation of maxim of manner. It showed that violation of maxim of manner was the lowest number in scripts Dodit Mulyanto in Stand Up Comedy Indonesia Kompas TV season 4. Dodit Mulyanto seldom violated the maxim of 
manner because it tends to use ambiguous or violates the utterances that have obscurity. Here were some examples of dialogues which violated each maxim.

After discussing about the maxim violation done by Dodit Mulyanto, here are some of the finding examples about the violation of politeness principle and cooperative principle and discussion and the using of maxims violation done by Dodit in order to rise humor.

1. Violation of Maxim of Quantity

Example 1:

Kentongan itu ada artinya, kalo dipukul sekali "tuk” “ tuk” “ tuk” sedang terjadi peristiwa pembunuhan. Ya, serius di desa tu seperti itu. Kemudian kalo ada bunyi dua kali "tuk tuk" "tuk tuk" sedang terjadi pencurian, kemudian kalo dipukul bunyinya gini (memukul seperti penjual mie ayam) maaf kentongannya dibajak.[Penonton tertawa dan tepuk tangan]. (P.3 L.3-7).

\section{$\underline{\text { Translation }}$}

Kentongan has a variety of meanings, if it is hit once "tuk" "tuk" "tuk". it means there is a murder. Yes, seriously. That what happen in the village. Then, if it is hit twice "tuktuk" "tuktuk" it means the event of theft, then if it is hit like this (knocking such as chicken noodle seller) sorry, the kentongan has been hijacked [the audiences laugh and applause].

$\underline{\text { Analysis }}$

This sentence was violated maxim of quantity, the researcher found an unnecessary sentence in the last of the paragraph, the sentence is: "then if it is hit like this (such as chicken noodle seller) sorry, the kentongan has been hijacked", this information is not required by the audience, but Dodit adds this in order to raise humor.

Example 2:

Saya makan itu table manner, peralatannya harus lengkap ada sendok, garpu, silet[Penonton tertawa] (P.2 L.2-3).

\section{$\underline{\text { Translation }}$}


I used to eat with table manner, the equipment must be complete: spoon, fork, and blade [the audiences laugh].

$\underline{\text { Analysis }}$

This second sentence violated maxim of quantity, the word "blade" in the last of the sentence should not be mentioned or may be replaced with the word "knife", because a blade is not included in the table manner equipment or not used as tableware, but this kind of violation has raises humor among the audience successfully. The context of his speech is that Dodit want to explain about his breakfast. As the Javanese family that embrace European culture the breakfast in his family conducted in table manner, but in fact he has mistaken in mentioning the table manner stuffs.

2. Violation of Maxim of Quality

Example 1:

Saya itu dilahirkan istimewa, saya dilahirkan secara otodidak, [Penonton tertawa] saya lahir bidannya baru datang, jadi saya keluar sendiri [Penonton tertawa]. (P.3 L.12).

\section{$\underline{\text { Translation }}$}

I was born specially, I was born autodidactly [the audiences laugh], and when I was born the midwife came late, so I go out alone [the audience laugh].

$\underline{\text { Analysis }}$

According to Dodit, his born was very special, even he can go out from his mother's womb by himself. This utterance violated maxim of Quality, because he said something that he believe to be false. Moreover, no body belief that the baby could go out by himself without any helping from nurse.

Example 2:

Saat saya pertama kali stand up, saya tu sangat takut menatap mata penonton, saking takutnya saya menatap mata saya sendiri[penonton tertawa] (P.3 L.1-2).

$\underline{\text { Translation }}$ 
My father does not let me chase a kite, I was only allowed to chase you...[the audiences laugh] I love you! [the audiences laugh].

\section{$\underline{\text { Analysis }}$}

This sentence violated maxim of relation, it is approved with the first sentence: "My father do not let me chase a kite" which has no relation with the second sentence: "I was only allowed to chase you... I love you". In this case, the audience was thinking that Dodit's father didn't allow him to chase a kite because he afraid Dodit will be dirty, tired and looks plebeian. But in fact, Dodit answered it because he only allowed to chase a beautiful woman. If the sentence is changed like: My father does not let me chase a kite, because he afraid I will be tired. The sentence doesn't rise humor effect. The context here is that Dodit is trying to be a romantic man like a classic European man who really adhere women by using his own words to flirt the girl.

4. Violation of Maxim of Manner

Example 1:

Tau kan Presiden kita sukanya baris-berbaris? Piyekabare? [penonoton tertawa] Iseh penak jamanku tho? [penonoton tertawa] \#akurapopo (P.1 L.2-4)

Translation

Do you know our former president who loves marching? How are you? [the audiences laugh] Is my decade still the best? [the audiences laugh] \#I am okay. $\underline{\text { Analysis }}$

This sentence made some audience do not understand about who is the president that being told by Dodit. Hence, this sentence violated maxim of manner. This sentence was found after Dodit singing the mars of general election, after singing he explained that the song was created by the president at that time. Because the president was a former general of armed forces so the song beat was very fast like a marching soldiers, furthermore he tried to ask the audience who the president was by giving a code sentence. Example 2:

koruptor jahat! (P.7 L.4) 
$\underline{\text { Translation }}$

the corruptors are criminals!

$\underline{\text { Analysis }}$

In the last of his speech, Dodit said the sentence above without any reason and without any foreword and makes the audience confused. At the end, the audience laugh at this ambiguity. Because this sentence is unclear, so it has violated maxim of manner. The context is when Dodit delivers a speech that he was confused with the condition of this nation, then he plays a fast rhythm by his violin and in the last he said the sentence, of course the audiences amazed with his ambiguity.

\section{CONCLUSION}

After conducting research and analyzing the research problems about cooperative principle, it is concluded that Dodit Mulyanto violates all of the four maxims of cooperative principle: maxim of Quantity, maxim of quality, maxim of relation, and maxim of manner. There was found twelve data on the maxim of quantity violation, whereas the maxim of quality violated in thirteen data, maxim of relation is the most frequent maxim to be violated, it is proved by the research finding that it was violated twenty two times. Hence, the fewest violation occurred on the maxim of manner which only occurred two times.

Dodit has violated maxims of cooperative principle in various ways in order to raise humor of the audience. Maxim of quantity has violated by Dodit Mulyanto by adding an unnecessary sentence to his information and those unnecessary additional information succeeds to raise humor. Dodit violated maxim of quality by telling lies and saying something that is believed to be false by the audience. Whereas maxim of relation violated by Dodit by making the speech which is unmatched with the topic or his own statement before. Moreover, Dodit violated maxim of manner by using ambiguous language. In addition, Dodit is doing all of these violations only to raise humor among the audience and not for the other purpose.

The violation of cooperative principle is not always become a bad thing in communication. On the contrary, it and may be applied in daily life in order to make a joke, to perform stand up comedy or public speaking, to make teaching method more interesting for 
the teacher or lecturer and of course, it may be researched again in depth in order to enrich the knowledge about humor based on linguistic approach.

\section{REFERENCES}

Attardo, S.,\& Ruskin (1991). Linguistic Theories of Humor. Mouton de Gruyter. New York.

Arikunto, S. (1990). Metode Penelitian. Jakarta: Rineka Cipta.

Arikunto, S. (1997). Prosedur Penelitian. Jakarta: PT Bina Angkasa.

Čapková, E. (2012). Pragmatic Principles and Humor in the IT Crowd (Unpublished bachelor thesis). Republic of Czechoslovakia: Masaryk University.

Crossman, A. (2015). Units of Analysis. Retrieved from http://sociology.about.com/od/Research/a/Units-Of-Analysis.htm. Retrieved on 17 may 2014 at $10.00 \mathrm{am}$.

Crystal, D. (1987). The Cambridge Encyclopedia of Language. Cambridge: Cambridge University Press.

Damayanti, Y. (2011). Flouting Maxims Found in Kung Fu Panda Movie Script Written by Jonathan Aibel and glenn berger (Unpublished bachelor thesis).Semarang: Semarang State University.

Darojat, A. (2011). An Analysis on the Violations of Politeness Principles Used in English Conversation in "Son of Ranbo" movie (Unpublished Bachelor thesis). Salatiga: State Institute for Islamic Studies (STAIN), Salatiga.

Derrida, J.(2002). Who's Afraid to Philosophy. California: Standford University Press,

Diessel, H. (2011). Language Form, Function and Communication. Retrieved from http://www.personal.uni jena.de/ x4diho/ INTRO_Language_form_function_and_communication.pdf

Grundy, P. (2000). Doing Pragmatics second edition. London: Arnold.

Kasper, G. (1997), Can Pragmatic Competence be Taught?, Second Language Teaching \& Curriculum Center, Retrieved fromwww.nflrc.hawaii.edu/NetWorks/NW06 on 27 January 2015. 
Kesuma, T.M. (2007). Pengantar Metode Penelitian Bahasa. Yogyakarta: Carasvatibooks.

Khosravizadeh, P., \& Nikan, S. (2011).Some Instances of Violation and Flouting of the Maxim of Quantity by the Main Characters (Barry \& Tim) in Dinner for Schmucks. 2011 International Conference on Languages, Literature and Linguistics IPEDR vol.26. Singapore: IACSIT Press.

Leech, G. (1983). Principle of Pragmatics. London and New York: Longman group Limited.

Levinson, S.C. (1983). Pragmatics. Cambridge: Cambridge University Press.

Longman advanced American dictionary. (2007). USA: Longman Ltd.

Mustikasari, R.D.W. (2010). Teachers' directives in the immersion pre-school classrooms of the Mondial School the Academic Year of 2009/2010 (Unpublished Master thesis). Semarang: Semarang State University.

Moore, A. (2003). Introduction to the Study of Language. Retrieved from http: // www. Universalteacher. org.uk/ lang/ pragmatics. Htm \#17. Retrieved on 25 August 2014 at $10.00 \mathrm{am}$.

Noviana, F. (2011). Penyimpangan Prinsip Kerja Sama pada Pemakaian Bahasa Percakapan dalam Interaksi Belajar Mengajar Bahasa Indonesia serta Aplikasinya dalam Pengajaran Keterampilan Berbicara Siswa kelas XI SMK Negeri 1 Seyegan Sleman Yogyakarta (Unpublished Bachelor thesis). Yogyakarta: Yogyakarta State University.

Nugroho, P. (2011), Potret Stand Up Comedy. Yogyakarta: Pustaka Baru Press.

Purwanti, E. (2006). Penyimpangan Maksim-maksim Prinsip Kesopanan dalam Komedi Extravaganza (Unpublished Bachelor thesis). Yogyakarta:Gadjah Mada University.

Rini, S. (2010). Violating the Maxims of Quality and Quantity on the 'Demo Sabun' Sketch of Extravaganza Situation Comedy TV. Register Language and Language Teaching Journals. ISSN 1979-8903. November 2010, Volume 3, No 2.

Ross, A. (1998). Language of Humour. London: Routledge.

Saerozi et al.,(2009).Pedoman Penulisan Skripsi. Salatiga: STAIN Salatiga Press.

Siswantoro.(2010). Metode Penelitian Sastra; Analisis Struktur Puisi, Yogyakata: Pustaka Pelajar.

Spatt, B. (2007). Writing from Sources seventh edition. Boston, MA: Bedford / St. Martin's. 
Thomas, J. (1995). Meaning in Interaction: An Introduction to Pragmatics. London: Longman.

Tupan, A.H., \&Helen, N. (2008).The Multiple Violations of Conversational Maxims in Lying Done by the Characters in Some Episodes of Desperate Housewives. "Kata" Journal, June 2008, volume 10, number 1, page: 63-78. English Department, Faculty of Letters, Surabaya: Petra Christian University.

Watts, R.J. (2003). Politeness. Cambridge: Cambridge University Press. 